\title{
Contribution of the Facilities Completeness and Learning Interests on Student Practical Capabilities in Broad-Based Network Technology Subject
}

\section{Kardimen Novajri1*, Hasan Maksum², Eko Indrawan Dedy Irfan ${ }^{3}$}

${ }^{123}$ Technology and Vocational Education Study Program, State University of Padang, Indonesia

\begin{tabular}{l} 
A R T I C L E I N F O \\
\hline Article history: \\
Received 10 December \\
2020 \\
Received in revised \\
Form 06 January 2021 \\
Accepted 1 February 2021 \\
Available online 09 \\
February 2021
\end{tabular}

Keywords:

Practical Facilities,

Learning Interest,

Practice Capability

\begin{abstract}
A B S T R A C T
Based on the preliminary observations that have been done, it was found that the students' practice skills were still low in the area-based network technology subject. Based on the agreed value standard, the minimum score in productive subjects is 80 , so the results of the students' practical capability show that it has not been fully achieved. This research is qualitative research with a correlational approach, which aims to reveal how much the practical facilities completeness and students' interest in learning to practical skills in the areabased network technology subject. The population of this study was students of class $\mathrm{XI}$, which consisted of 34 students. At the same time, the sample was taken from a population of 25 students. The data was collected using a questionnaire, and the value of practice and the data were analyzed using correlation and regression techniques. Based on the data analysis, it was found that: completeness of practical facilities contributed $28 \%$ to practical skills, learning interest contributed $34.2 \%$ to practical capabilities, completeness of practical facilities and interest in learning together contributed $82.3 \%$ to the ability practice.
\end{abstract}

\section{Introduction}

Practicality is the ability and strength of a person to solve a problem or work, referring to certain rules or norms (Lafianto, 2013). A person's abilities are influenced by several basic factors or aspects such as intelligence, strength, and proficiency. If there is one can finish the job with a good result and in a short time. Then the person has a great ability and vice versa. The practice is a part of teaching, which aims to allow the students to test and carry out real circumstances about the theory they have obtained (Nugroho \& Samidjo, 2013; Saputra \& Azhar, 2019). The practice is also defined as exploring or carrying out what has been studied previously in theory.

The department's learning program serves to equip students with standard competencies or productive abilities in a particular occupation or expertise relevant to the job market's demands and demands (Saputra \& Azhar, 2019; Yulianti \& Khafid, 2015). This program emphasizes the provision of mastery of student competence, including knowledge, skills, and attitudes (Nurhasanah \& Sobandi, 2016). Based on the preliminary observations that have been done, there are still low results of practical skills that have been obtained by students in the subjects of Broad-Based Network Technology. Based on the agreed grade standards, the minimum score in productive subjects is 80 , so the results of the student's practical ability show it has not been fully achieved. It can be seen in Table 1.

Tabel 1. Students' Score Data

\begin{tabular}{cccccc}
\hline \multirow{2}{*}{ No } & Class & Number of & \multicolumn{3}{c}{ The score obtained } \\
\cline { 4 - 6 } & & Students & $\mathbf{> 8 0}$ & $\mathbf{8 0}$ & $<\mathbf{8 0}$ \\
\hline 1 & $\mathrm{XI} \mathrm{TKJ}$ & 34 & 12 & 7 & 15 \\
\hline
\end{tabular}

From Table 1, it can be seen that the percentage of learning outcomes of broad-based network technology subject of grade XI students in 2019/2020 who scored >80 (12 students), 80 ( 7 students), and $<80$ (15 students). From the data can be categorized that 15 students got a score below minimum mastery criteria (KKM), seven students got minimum mastery criteria limit to score, and 12 students got a score above the minimum mastery criteria. Besides the value problem, based on observations in the field at the 
time of practice, there are still students who do not focus. It is due to the limited number of equipment that existed in the workshop. The use of tools is done alternately by the group. One group of 6 students is even more. Ideally, the tool is 1 group maximum for three people. The limitations of this practice equipment have an impact on the low interest of students during the practice.

Students ' learning outcomes are influenced by the factors that affect learning outcomes and are influenced by two main factors, namely internal and external factors (Pratiwi, 2017; Siagian, 2015). Internal factors come from within students, including ability, talent, interests, motivation, and selfconcept. In contrast, external factors are factors that exist outside the students, namely: teachers, parents, curriculum, facilities, and infrastructure, and classroom conditions (Iriani \& Soeharto, 2015; Pratiwi, 2017). Factors that affect learning outcomes of the practice capabilities inside and outside the student are the interest and practice facilities. Because interests and practical facilities can attract students to learn and obtain good learning outcomes. Because each student has different characteristics and different external influences (Riwahyudin, 2015; Siagian, 2015).

Learning facilities are closely related to the way students learn. The completeness of adequate facilities can facilitate the acceptance of lesson materials provided to students. If students are easy to receive lessons and master them, they will become more enterprising and advanced. Practical facilities are seen and the availability of facilities only and seen and complete and adequate facilities used. For example, if a tool is available but not sufficient to use, the student will be less satisfied (Kartika, Husni, \& Millah, 2019). In contrast, if the tool is available and good to use, the student will feel satisfied. Then, this will give rise to a desire to do it continuously, and students will be more creative and skilled in using tools. The completeness of practical facilities in terms of quality and quantity has a big influence on practical capabilities. The availability of adequate practice facilities will generate students' interest in learning and make the learning process more effective and efficient. In the end, it can improve the students' ability to conduct practical activities. Facilities can be in the form of equipment, even the equipment used by teachers to help the implementation of the learning process (Putra \& Widodo, 2009; Setiawati \& Sudira, 2015).

Psychologists have defined many interests and variations. But basically, those opinions complement each other. Interest is a sense of preference (pleasure) and a purpose of attraction to a thing or activity. Feelings are a non-intellectual psychological factor that affects students' spirit or passion in carrying out learning. Feelings of pleasure will generate interest that is reinforced again by a positive attitude (Fimansyah, 2015). Interest is also defined as high tendencies and passions or a great desire for something and can cause attention to the activity. While the interest is always followed by a feeling of pleasure and from it obtained chilling satisfaction. If a student is interested in a lesson's success in the world of education, then the student must enjoy the lesson. Then, indirectly students will pay attention to the knowledge that supports the success of the lesson. Attention is a common reaction of organisms and consciousness that causes increased activity-concentration and consciousness restriction on an object. Feelings, moods strongly influence attention and also will. Attention is considered to be an effect of psychic ability called interest (Nurhasanah \& Sobandi, 2016).

Interest has defined the ability to provide stimulation that encourages students to pay attention to a person, object, activity, or something that can contribute to an experience that the activity itself has stimulated (Baiti \& Munadi, 2014; Siagian, 2015). Interest is one thing that determines a person's success in all fields, both in the study, work, and other activities. Interest in a particular field will bring spontaneous attention to the field. The presence of interest raises attention and makes it easier for someone to consign to the field or activities. Concentration is an accidental result and attention caused by an interest in something. Students interested in the lesson and train themselves to continue learning can gradually enlarge their concentration ability. In this case, a student interested in the lesson's success is when the student realizes how important the lesson's success is. The willingness to encourage students' interest encourages the movement of activities towards the achievement of a goal. The symptoms will require the existence of implementation activities. Willingness here is a motivation from within with awareness, based on consideration of thoughts and feelings that lead to targeted activities on achieving certain goals related to their needs (Cahyono, Pratama, Rani, 2020; Santi, 2014).

This study aims to analyze the extent of the contribution of completeness of practical facilities and students' learning interests to students' practical computer and network engineering skills competencies at SMK Negeri 1 Matur in broad-based network technology subjects.

\section{Methods}

This research method is a descriptive correlational research method. This study aims to determine how much the contribution of completeness of practical facilities and interest in learning. As 
free variables (X1) and (X2) to the ability of practical students on the competence skills of computer engineering and networks in SMK Negeri 1 Matur as variable bound (Y), and the relationship between the two free variables (X1) and (X2) simultaneously to the bound variable (Y). The research setting was at SMKN 1 Matur, located in the Agam district of West Sumatra province. This setting was chosen because the researchers taught at SMK Negeri 1 Matur.

The population in this research is 34 students with the competence skills of computer engineering and networks. The sampling technique used is Simple Random Sampling. Samples were taken by lottery. Sampling technique using the formula from TaroYamane, Riduwan (2006:65) as follows:

$$
n=\frac{N}{N_{n} d^{2}+1}
$$

Description:

$\mathrm{n}=$ Number of Samples

$\mathrm{N}=$ Population

$\mathrm{D}=$ Specified precision (used 10\%)

Based on the formula that can be obtained, samples are:

$$
n=\frac{a 4}{\left(24 x 0,1^{2}\right)+1}=25,37 \approx 25
$$

The hypothesis testing technique of this study was conducted with correlation analysis techniques. This analysis can be done when fulfilling several requirements, namely the normality test of each data, homogeneity test, and linearity test. Data normality testing is intended to test the assumption that information is normally distributed. The normality test was conducted using the One-sample Kolmogorov-Smirnov test. The degree of significance is used as the basis for rejecting or accepting the normal decision or whether a data distribution is 0.05 . Declared normal distribution if the significance value is greater than $5 \%$ or 0.05 . A homogeneity test is a test conducted to see if the data obtained comes from a homogeneous sample. Homogeneous sample data if the value of significance is large of 0.05 . The linearity test aims to determine whether two variables have a significant linear relationship. This test is used as a prerequisite in correlation analysis or linear regression. Two variables are said to have a linear relationship when the value of significance is greater than 0.05 .

\section{Result and Discussion}

\section{Descriptive Analysis Results}

This research data includes three variables, namely variable completeness of practical facilities $\left(\mathrm{X}_{1}\right)$, interest in learning $\left(\mathrm{X}_{2}\right)$, practical capabilities $(\mathrm{Y})$. From the research results that have been done on the data, all incoming data is eligible to be processed and analyzed. It can be briefly stated that this data description reveals information about the total score, highest score, lowest score, average, range, standard deviation, emerging score, and middle score. The results of the descriptive analysis are shown in Table 2.

\begin{tabular}{|c|c|c|c|c|}
\hline Statistical & & $\begin{array}{l}\text { Practical } \\
\text { Capabilities }\end{array}$ & $\begin{array}{l}\text { Facilities } \\
\text { Completeness }\end{array}$ & Interest \\
\hline \multirow[t]{2}{*}{$\mathrm{N}$} & Valid & 34 & 34 & 34 \\
\hline & Missing & 0 & 0 & 0 \\
\hline Mean & & 79.59 & 89,59 & 115.29 \\
\hline Median & & 80.00 & 88.00 & 117.00 \\
\hline Mode & & 80 & $85^{a}$ & 123 \\
\hline Std. Deviation & & 6.787 & 10.305 & 12.918 \\
\hline Variance & & 46.068 & 106.189 & 166.881 \\
\hline Range & & 36 & 46 & 53 \\
\hline Minimum & & 55 & 64 & 81 \\
\hline Maximum & & 91 & 110 & 134 \\
\hline Sum & & 2706 & 3046 & 3920 \\
\hline
\end{tabular}

Table 2. Descriptive Analysis Results 


\section{Analysis Prerequisite Test Results}

The results of the normality test calculation can be seen in Table 3 .

Table 3. Normality Test Summary

\begin{tabular}{lllll}
\hline \multicolumn{1}{c}{ Statistics } & X1 & X2 & Y \\
\hline \multirow{4}{*}{ Normal Parameters } & $\mathrm{N}$ & 34 & 34 & 34 \\
& Mean & 89.59 & 115.29 & 79.59 \\
& Std. Deviation & 10.305 & 12.918 & 6.787 \\
& Absolute & .122 & .113 & .123 \\
MostExtremeDifferences & Positive & .111 & .074 & .123 \\
& Negative & -.122 & -.113 & -.117 \\
\hline \multicolumn{2}{c}{ Kolmogorov-Smirnov Z } & $\mathbf{. 7 1 2}$ & $\mathbf{. 6 6 1}$ & $\mathbf{. 7 1 6}$ \\
\hline \multicolumn{2}{c}{ Asymp. Sig. (2-tailed) } & $\mathbf{. 6 9 0}$ & $\mathbf{. 7 7 5}$ & $\mathbf{. 6 8 4}$ \\
\hline
\end{tabular}

From Table 3, it can be seen that the Kolmogorov-Smirnov significance score for variable $\mathrm{Y}$ is 0.684 , variable $\mathrm{X}_{1}$ is 0,690 , and variable $\mathrm{X}_{2}$ is 0.775 . Because the significance for all variables is higher than 0.05 , it can be concluded that the data on the variable's Practical capability, Facilities completeness, and Interest in Learning are normally distributed. The results of the summary of the data homogeneity test can be seen in Table 4 .

Table 4. Homogeneity Test Summary

\begin{tabular}{cccccc}
\hline & Statistics & Levene Statistic & df1 & df2 & Sig. \\
\hline Based onMean & 1.056 & 2 & 99 & .352 \\
Value & 1.079 & 2 & 99 & .344 \\
& $\begin{array}{c}\text { Based on Median } \\
\text { Based on Median and with } \\
\text { adjusted df }\end{array}$ & 1.079 & 2 & 89.425 & .344 \\
& Based on trimmed mean & .935 & 2 & 99 & .396 \\
\hline
\end{tabular}

From the table above, it appears that the sign indicates that it is higher than 0.05 . Based on this significance, it can be said that the data distribution comes from homogeneous samples. The results of the meaninglessness and linearity of regression equations test are presented in Table 5.

Table 5. The Linearity Test Summary

\begin{tabular}{|c|c|c|c|c|c|c|c|}
\hline & Statistics & & $\begin{array}{l}\text { Sum of } \\
\text { Squares }\end{array}$ & df & & $\mathbf{F}$ & Sig. \\
\hline \multirow{5}{*}{$\mathrm{Y}^{*} \mathrm{X} 2$} & \multirow{3}{*}{$\begin{array}{l}\text { BetweenGr } \\
\text { oups }\end{array}$} & (Combined) & 1559.765 & 21 & 74.275 & .744 & .733 \\
\hline & & Linearity & 5.527 & 1 & 5.527 & .055 & .818 \\
\hline & & $\begin{array}{c}\text { DeviationfromLi } \\
\text { nearity }\end{array}$ & 1554.237 & 20 & 77.712 & .778 & .700 \\
\hline & \multicolumn{2}{|c|}{ WithinGroups } & 1198.000 & 12 & 99.833 & & \\
\hline & \multicolumn{2}{|r|}{ Total } & 2757.765 & 33 & & & \\
\hline
\end{tabular}

Based on the table above, the significant value of deviation from linearity is $0.700>005$. From the results of this analysis, it can be concluded that between the variables of completeness of practical facilities and the interest in learning to practice skills, there is a linear relationship

\section{Hypothesis Testing \\ Practical Facilities for Practical Skills}

Based on the results of the analysis, the value of sig. (2-tailed) indicates that it is smaller than 0.05 i.e. $0.000<0.005$. It can then be concluded that there is a significant relationship between the practice 
facility $\left(\mathrm{X}_{1}\right)$ and the practical ability $(\mathrm{Y})$. A summary of the analysis results of practical facilities' contribution to practice is presented in Table 6.

Table 6. Summary of Contribution Analysis Results $X_{1}-Y$

\begin{tabular}{cccccc}
\hline Correlation & Coefficient $(\mathbf{r})$ & $\begin{array}{c}\text { Coefficient } \\
\text { Determination }\left(\mathbf{r}^{\mathbf{2}}\right)\end{array}$ & T count & T table & Sig. \\
\hline $\mathrm{r}_{\mathrm{y} 1}$ & 0,532 & 0,2830 & 3,554 & 2,080 & 0,000 \\
\hline
\end{tabular}

Interest in Learning Practical Skills

Based on the results of the analysis of sig values. (2-tailed) indicates that it is smaller than 0.05 i.e. $0.000<0.005$. It can then be concluded that there is a significant relationship between learning interests $\left(\mathrm{X}_{2}\right)$ and practical abilities $(\mathrm{Y})$. A summary of the analysis results of the contribution of learning interest to practical skills is presented in Table 7.

Table 7. Summary of Contribution Analysis Results $X_{2}-Y$

\begin{tabular}{cccccc}
\hline Correlation & Coefficient $(\mathbf{r})$ & $\begin{array}{c}\text { Coefficient } \\
\text { Determination }\left(\mathbf{r}^{2}\right)\end{array}$ & T count & T table & Sig. \\
\hline $\mathrm{r}_{\mathrm{y} 2}$ & 0,585 & 0,342 & 4,079 & 0,2080 & 0,000 \\
\hline
\end{tabular}

\section{Contribution of Practical Facilities Completeness and Learning Interests to Practical Skills}

A summary of the correlation analysis results of practical facilities' completeness and the interest in learning to practical abilities is presented in Table 8.

Table 8. Third Hypothesis Correlation

\begin{tabular}{ccccc}
\hline Model & R & R Square & $\begin{array}{c}\text { Adjusted R } \\
\text { Square }\end{array}$ & $\begin{array}{c}\text { Std. } \\
\text { Errorofthe } \\
\text { Estimte }\end{array}$ \\
\hline 1 & .907 & .823 & .812 & 2.946 \\
\hline
\end{tabular}

Based on Table 8 obtained the number $\mathrm{R}^{2}$ (R square) of 0.823 or ( $82.3 \%$ ) this indicates that the percentage of independent variable influence contributions (completeness of facilities and learning interests) to dependent variables (practical ability) is $82.3 \%$. In contrast, the remaining $17.7 \%$ were influenced or explained by other variables not included in the study.

The third hypothesis is that there is a contribution of practical facilities completeness and interest in learning together to the practical ability of Broad-Based Network Technology subjects in SMK Negeri 1 Matur. This hypothesis was tested using the $\mathrm{F}$ test to determine the contribution to practical capabilities.

Table 9. F Test Table

\begin{tabular}{ccccccc}
\hline & Model & Sum of squares & Df & MeanSquare & F & Sig. \\
\hline \multirow{2}{*}{1} & Regression & 1251.193 & 2 & 625.597 & 72.084 & $.000^{\mathrm{a}}$ \\
\cline { 2 - 7 } & Residual & 269.042 & 31 & 8.679 & & \\
\cline { 2 - 7 } & Total & $\mathbf{1 5 2 0 . 2 3 5}$ & $\mathbf{3 3}$ & & & \\
\hline
\end{tabular}

\section{Discussion}

\section{Practical Facilities for Practical Skills}

The analysis results obtained a t-count of 3,554 with a significance of 0.000 , which means $\mathrm{H} 0$ was rejected. With $\mathrm{H}_{0}$ is rejected, then $\mathrm{H}_{1}$ is accepted. There is a contribution of completeness of practical facilities to Broad-Based Network Technology subjects' practical capabilities in SMKN 1 Matur. The contribution between the practical facilities completeness to practice is $(0.532) 2 \times 100 \%=28 \%$. So, the completeness of practical facilities contributes to the ability of practical facilities by $28 \%$. It is supported by the study of the theory that the completeness of practical facilities both in terms of quality and quantity has a big influence on students' ability (Lafianto, 2013; Nugroho \& Samidjo, 2013; Saputra \& Azhar, 2019). 
Because with the availability of adequate practice facilities, it will be able to generate students' interest in learning and make the learning process more effective and efficient. In the end, it can improve the ability of students to conduct practical activities. Facilities can be in the form of equipment and equipment used by teachers to help implement the learning process. Learning facilities are closely related to the way students learn. Adequate facilities can facilitate the acceptance of lesson materials provided to students. If students are easy to receive lessons and master them, they will become more enterprising and advanced.

\section{Interest in Learning Practical Skills}

The analysis results obtained a t count of 4,079 with a significance of 0.000 , which means $\mathrm{H}_{0}$ is rejected. With $\mathrm{H}_{0}$ is rejected, then $\mathrm{H}_{1}$ is accepted. There is a contribution of an interest in learning to the capabilities of broad-based network technology subjects in SMKN 1 Matur. The amount of contribution between Learning Interests to practical skills is $(0.585) 2 \times 100 \%=34.2 \%$. So, students' learning interests can contribute to learning outcomes by $34.2 \%$. The second hypothesis test result is that there is a contribution of an interest in learning to the practical skills of Broad-Based Network Technology subjects in SMKN 1 Matur. This hypothesis was tested using a meaning test with a t-test. The amount of contribution between Learning Interests to practical skills is $34.2 \%$. It is supported by theoretical studies that suggest that interest is the ability to provide stimulation that encourages students to pay attention to a person, object, activity or something that can contribute to the experience that the activity itself has. Interest is one thing that determines a person's success in all fields in the study, work, and other activities. Interest in a particular field will bring spontaneous attention to the field. Interest is raising attention and making it easier for someone to focus on the field or activities they live in (Fimansyah, 2015; Kartika et al., 2019).

\section{Contribution of Practical Facilities Completeness and Learning Interests to Practical Skills}

Based on the sig value of the regression indicating that smaller than 0.05 is $0.000<0.05$. So, it can be concluded that $\mathrm{H}_{0}$ is rejected and $\mathrm{H}_{1}$ is accepted, which means that there is a significant relationship between the practice facility $\left(\mathrm{X}_{1}\right)$ and the learning interest $\left(\mathrm{X}_{2}\right)$ to the practical ability $(\mathrm{Y})$. The analysis results obtained an $F$ count of 72,084 with a significance of 0.000 , while the $F$ table's value if the significance level of 0.05 of $3.028 \mathrm{H}_{0}$ is rejected. With $\mathrm{H}_{0}$ rejected, $\mathrm{H}_{1}$ is accepted, there is a contribution of completeness of practical facilities and interest in learning together to the practical ability of broad-based network technology subjects in SMK Negeri 1 Matur.

The analysis results obtained an F count of 72,084 with a significance of 0.000 , while the F table's value if the significance level of 0.05 of $3.098 \mathrm{H}_{0}$ is rejected. With $\mathrm{H}_{0}$ rejected, $\mathrm{H}_{1}$ is accepted. So, there is a contribution of completeness of practical facilities and interest in learning together to the practical ability of broad-based network technology subjects in SMK Negeri 1 Matur. The results of data analysis and hypothesis testing showed that the three hypotheses tested in this study were empirically accepted. From each predictor's contribution to practical capabilities, practical facilities' completeness contributes to the practical capabilities by $28 \%$ and interest in learning by $34.2 \%$. While the contribution together from the practical facilities completeness and interest in learning to the ability of $82.3 \%$. The results showed that the practical facilities' completeness and learning interests contributed significantly to practice. This study found that each variable studied in the subjects of Broad-Based Network Technology SMK Negeri 1 Matur showed a significant contribution to the practical capabilities, both the variables stand-alone and together. It shows that problems in the students' practical capabilities are also influenced by the completeness of practical facilities and students' learning interests.

\section{Conclusion}

Based on the data, data analysis, and discussion presented in the previous chapter, the study results can be concluded as follows: A positive and significant contribution of practical facilities completeness to students' practical ability 28\% in SMKN 1 Matur. The more adequate practical facilities' practical facilities, the more practical skills in Broad-Based Network Technology subjects tend to be increased; there is a positive and significant contribution between students' learning interest in practical skills 34.2\% in SMKN 1 Matur. Namely, the higher interest in students learning means the more practical skills in Broad-Based Network Technology subjects tends to be increased. There is a positive and significant contribution between the practical facilities completeness and the mutual interest in learning to the practical capabilities of $82.3 \%$ in SMKN 1 Matur. It means that the more adequate the completeness of practical facilities and the higher the interest in learning students, the more practical capabilities in Broad-Based Network Technology subjects are likely to increase. 


\section{References}

Baiti, A. A., \& Munadi, S. (2014). Pengaruh Pengalaman Praktik, Prestasi Belajar Dasar Kejuruan dan Dukungan Orang Tua Terhadap Kesiapan Kerja Siswa SMK. Jurnal Pendidikan Vokasi, 4(2). https://doi.org/10.21831/jpv.v4i2.2543

Cahyono, D., Pratama, A., \& Rani, H. A. D. (2020). Pengembangan Video Pembelajaran untuk Meningkatkan Hasil Belajar Peserta Didik di Smk Negeri 1 Kempas Kelas XI pada Mata Pelajaran Teknologi Jaringan Berbasis Luas (WAN). Joined Journal (Journal of Informatics Education), 3(1), 52-61. https://doi.org/10.31331/joined.v3i1.1075

Fimansyah, D. (2015). Pengaruh Strategi Pembelajaran dan Minat Belajar Terhadap Hasil Belajar $\begin{array}{lllll}\text { Matematika. Judika UNarnal Pendidikan } & \text { UNSIKA), }\end{array}$ https://journal.unsika.ac.id/index.php/judika/article/view/199

Iriani, D. S., \& Soeharto, S. (2015). Evaluasi Pelaksanaan Praktik Kerja Industri Siswa Kompetensi Keahlian Jasa Boga SMK N 3 Purworejo. Jurnal Pendidikan Teknologi dan Kejuruan, 22(3), 274-290. https://doi.org/10.21831/jptk.v22i3.6835

Kartika, S., Husni, H., \& Millah, S. (2019). Pengaruh Kualitas Sarana dan Prasarana Terhadap Minat Belajar Siswa dalam Pembelajaran Pendidikan Agama Islam. Jurnal Penelitian Pendidikan Islam,[SL], 7(1), 113-126. https://riset-iaid.net/index.php/jppi/article/view/360

Lafianto, P. (2013). Motivasi Dan Persepsi Siswa Tentang Kelengkapan Fasilitas Praktik Serta Pengaruhnya Terhadap Prestasi Belajar Siswa Kelas X SMK N 2. Jurusan Pendidikan Teknik Elektro, 2(1), 26-33. https://eprints.uny.ac.id/32378/1/Putaris\%20Lafianto\%20$\% 2007501241021 . p d f$

Nugroho, B. Y., \& Samidjo, S. (2013). Pengaruh Kelengkapan Fasilitas Praktik dan Kedisiplinan Siswa Terhadap Hasil Evaluasi Belajar Akhir Semester Mata Pelajaran Kerja Bangku Siswa Kelas I Jurusan Teknik Permesinan SMK Pembangunan Kutowinangun Kebumen Tahun Ajaran 2012/2013. Jurnal Taman Vokasi, 1(2). http://dx.doi.org/10.30738/jtv.v1i2.97

Nurhasanah, S., \& Sobandi, A. (2016). Minat belajar sebagai determinan hasil belajar siswa. Jurnal $\begin{array}{llll}\text { Pendidikan Manajemen Perkantoran } & \text { (JPManper), } & 1(1), & 128-135 .\end{array}$ https://doi.org/10.17509/jpm.v1i1.3264

Pratiwi, N. K. (2017). Pengaruh Tingkat Pendidikan, Perhatian Orang Tua, dan Minat Belajar Siswa Terhadap Prestasi Belajar Bahasa Indonesia Siswa SMK Kesehatan di Kota Tangerang. Pujangga, 1(2), 31. http://dx.doi.org/10.47313/pujangga.v1i2.320

Putra, A. I., \& Widodo, R. D. (2009). Pengaruh Pengalaman Praktik Kerja Industri Terhadap Minat Berwirausaha Pada Siswa Kelas XII Program Keahlian Teknik Mekanik Otomotif SMK Texmaco Pemalang. Jurnal Pendidikan Teknik Mesin, 9(1). http://ejournal.unp.ac.id/index.php/mpe/article/view/4240

Riwahyudin, A. (2015). Pengaruh Sikap Siswa dan Minat Belajar Siswa Terhadap Hasil Belajar IPA Siswa Kelas V Sekolah Dasar di Kabupaten Lamandau. Jurnal Pendidikan Dasar, 6(1), 11-23. http://journal.unj.ac.id/unj/index.php/jpd/article/view/427

Santi, M. E. (2014). Pengaruh Pengalaman Praktik Kerja Industri, Kompetensi Keahlian, dan Intensitas Pendidikan Kewirausahaan dalam Keluarga Terhadap Kesiapan Berwirausaha. Jurnal Pendidikan Humaniora, 1(2), 127-135. http://journal.um.ac.id/index.php/jph/article/view/4046

Saputra, N., \& Azhar, N. (2019). Kontribusi Konsep Diri dan Pemanfaatan Fasilitas Praktikum Terhadap Hasil Belajar Dasar Listrik Elektronika. VoteTEKNIKA: Jurnal Vocational Teknik Elektronika dan Informatika, 7(2), 105-110. http://ejournal.unp.ac.id/index.php/voteknika/article/view/104345

Setiawati, L., \& Sudira, P. (2015). Faktor-Faktor Yang Mempengaruhi Prestasi Belajar Praktik Kejuruan Siswa SMK Program Studi Keahlian Teknik Komputer dan Informatika. Jurnal Pendidikan Vokasi, 5(3), 325-339. https://doi.org/10.21831/jpv.v5i3.6487

Siagian, R. E. F. (2015). Pengaruh Minat Dan Kebiasaan Belajar Siswa Terhadap Prestasi Belajar $\begin{array}{lllll}\text { Matematika. Formatif: Jurnal Ilmiah Pendidikan } & \text { MIPA, }\end{array}$ http://dx.doi.org/10.30998/formatif.v2i2.93

Yulianti, I., \& Khafid, M. (2015). Pengaruh Pengalaman Praktik Kerja Industri, Motivasi Memasuki Dunia Kerja, dan Kemampuan Soft Skills Terhadap Tingkat Kesiapan Kerja Siswa Kelas XII Kompetensi Keahlian Akuntansi di SMK Negeri 2 Semarang Tahun Ajaran 2014/2015. Economic Education Analysis Journal, 4(2). https://journal.unnes.ac.id/sju/index.php/eeaj/article/view/6771 